The Israeli Journal of Aquaculture - Bamidgeh, IIC:63.2011.575, 7 pages

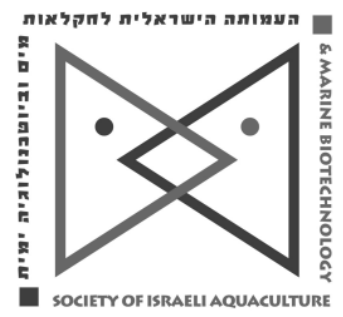

The IJA appears exclusively as a peer-reviewed on-line open access journal at http://www.siamb.org.il

Sale of IJA papers is strictly forbidden.

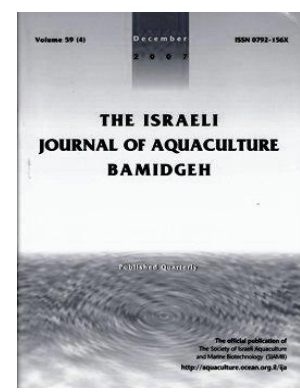

\title{
Offshore Farming of the Mediterranean Amberjack (Seriola dumerili) in the Northeastern Mediterranean
}

\author{
Erdal Yilmaz* and Hülya Şereflişan
}

\author{
Faculty of Fisheries and Aquaculture, Mustafa Kemal University, Kapalı \\ Yüzme Havuzu Yanı, Iskenderun Hatay, Turkey
}

(Received 4.5.10, Accepted 31.7.10)

Key words: Seriola dumerili, offshore, farming, feeding, Mediterranean

\begin{abstract}
The growth rate, survival, and feeding parameters of Mediterranean amberjack (Seriola dumerili Risso, 1810) cultivated in offshore cages in the Gulf of İskenderun (Hatay, Turkey) were investigated from July 2006 to March 2008. Two offshore cages $\left(339 \mathrm{~m}^{3}\right)$ were placed at a depth of $10 \mathrm{~m}$ in a sheltered area $500 \mathrm{~m}$ off the coast. Juveniles $(101.97 \pm 14.54 \mathrm{~g})$, caught with seine nets $400-1200 \mathrm{~m}$ from the coast, were stocked in the cages at 250 per cage. Fish in one cage, Group A, were fed commercial pellets for all 20 months whilst fish in the second cage, Group B, were fed pellets for the first 16 months and frozen sardines for the following four. The mean live weight, survival, feed conversion ratio, daily feed consumption, and water quality parameters were recorded monthly. Group B reached a significantly $(p<0.05)$ greater weight $(2785.00 \pm 64.91 \mathrm{~g})$ than Group A $(2441.14 \pm 38.13 \mathrm{~g})$. Food conversion ratios ranged $1.16-2.46$ for group $A$ and $1.10-2.28$ for group $B$, low when compared with other studies on amberjacks in the Mediterranean. Average mortality was $25 \%$, due to a Zeuxapta seriolae (Monogenea: Heteraxinidae) infection in December 2006 (20\%) and fish handling for measurement in June 2007 ( 5\%). The farmed amberjacks had significantly higher protein and lipid contents than their wild counterparts at the end of the 20-month feeding period. Amberjacks found frozen sardines more appealing than pellets, especially during the winter. In conclusion, it is advised to feed Mediterranean amberjack frozen sardines or other trash fish during the winter grow-out period. Their rapid growth rate, as well as their adaptability to farming, make offshore net cages a promising system for the aquaculture of this species.
\end{abstract}

\footnotetext{
* Corresponding author. Tel: +90-326-6141693/308, fax: +90-326-6141877, e-mail:
} yilmazerdal@hotmail.com 


\section{Introduction}

The Mediterranean amberjack, Seriola dumerili (Risso 1810), also referred to as the greater amberjack, is a carnivorous pelagic fish (Carangidae) that satisfies the criteria for selection of new aquaculture species (Marino et al., 1995), i.e., it has a rapid growth rate (Andaloro et al., 1992), easily adjusts to captivity, has excellent flesh quality, and is sold for a high market price (Nakada, 2000). It is distributed throughout tropical and subtropical regions except the Pacific Ocean (Laroche et al., 1984). In the eastern Atlantic, this species is distributed from the Bay of Biscay to South Africa, whereas in the western Atlantic, it inhabits the area from Nova Scotia to Brazil, including the Gulf of Mexico, the Caribbean, and Bermuda (Fischer, 1978). Amberjack is abundant in the Mediterranean area, except in the Black and north Adriatic Seas, (Andaloro et al., 1992).

The morphological and ecological characteristics of $S$. dumerili are similar to $S$. quinqueradiata which has been widely reared in Japan for over 25 years. Seriola dumerili is also reared in Japan and is imported from China to Japan. It has a high growth rate in the natural environment (Thompson et al., 1999) and in culture conditions (Jover et al., 1999; Mazzola et al., 2000). Hence, it has become one of the most important aquaculture species in the Mediterranean region as well as in Japan (Nakata, 2000; Takakuwa et al., 2006). It adapts easily to a captive environment but reproduction in culture conditions is difficult, although it has recently been successfully reproduced in Greece and Malta and Japanese scientists have successfully reared larvae since 1987 (Tachihara et al., 1993).

The commercial culture of $S$. dumerili in the Mediterranean is based on capture of wild juveniles that are fattened to marketable size (Lazzari et al., 2000; Pastor et al., 2000). On-growing in Mediterranean countries (Spain, Italy) as well as Japan generally occurs in net cages, using raw, fresh, frozen, or chopped fish (Sardinella aurita, Boops boops, Trachurus trachurus, Spicara maena). In the Mediterranean, juveniles have been reared in concrete tanks (Cavaliere et al., 1989; Garcia et al., 1993) and inshore net cages (Porrello et al., 1993). This investigation presents results of the cultivation of amberjack in offshore cages using simple low-cost installation techniques. Growth rate, survival, and feeding parameters of two groups of fish fed different diets in the northeastern Mediterranean were tested.

\section{Materials and Methods}

Feeding trials were carried out between July 2006 and April 2008 in the Gulf of İskenderun (Hatay, Turkey) in a sheltered area $500 \mathrm{~m}$ off the coast. Two offshore cages of $339 \mathrm{~m}^{3}$ (12 m diameter $\times 3 \mathrm{~m}, 12$ and $18-\mathrm{mm}$ mesh for juveniles and adults, respectively) were moored onto artificial reefs at a depth of $10 \mathrm{~m}$. Together with local fishermen, the research team caught juveniles $(101.97 \pm 14.54 \mathrm{~g})$ during the summer of 2006 using seine nets with 14-16 mm mesh, 400-1200 m from the coast. The fish were weighed and placed in a 2- $\mathrm{m}^{3}$ PVC tank on the fishing boat. The tank was equipped with a flow-through seawater system during transport to the cages. Two hundred and fifty fish were stocked into each cage as soon as possible.

The juveniles were fed three diets composed of frozen sardines (Sardina pilchardus) and pellets at rates of $75 / 25,50 / 50$, and $25 / 75$ for the first, second, and third months (July, August, and September 2006, respectively) to wean them to the dry commercial diet. Frozen sardines were initially offered in small minced pieces (heads removed) but, as the juveniles grew, the sardines were chopped to adequate sizes. After weaning, fish in one cage, Group A, were fed commercial pellets for 17 months and fish in the second cage, Group B, were hand-fed commercial pellets for 13 months (from November 2006 to to December 2007) and frozen sardines for the next 4 months. Fish were fed to satiation three times a day throughout the experimental period. The daily amount of food administered was recorded for both groups throughout the experimental period.

The mean body weight, specific growth rate, survival, feed conversion ratio, and total amount of food administered (as a function of body weight, \%) were calculated on a monthly basis. Growth performance data were analyzed as follows: daily specific growth rate $(\% /$ day $)$ in somatic live weight as $S G R=100\left[\left(W_{t} / W_{0}\right)^{1 / t}-1\right]$, where $W_{t}=$ weight on 
day $t, W_{0}=$ weight on day 0 , and $t=$ time elapsed in days; and the feed conversion ratio (FCR) as the amount of food consumed (dry weight in $\mathrm{g}$ ) divided by the growth in biomass (wet weight in $\mathrm{g}$ ) for a specific time period. Water quality parameters were measured on a daily basis, dissolved oxygen and temperature with a YSI 52 model oxygen meter (Yellow Springs Instruments Co., Ohio, USA), pH with an ORION 420A model, and salinity with an ATAGO hand refractometer.

At the end of the study, standard laboratory methods (AOAC, 1990) were used to determine the proximate compositions of fillets of the cultured and wild amberjacks as follows: moisture was determined by oven-drying at $105^{\circ} \mathrm{C}$ for $24 \mathrm{~h}$, crude protein $(\mathrm{N} \mathrm{x}$ 6.25 ) by the Kjeldahl method, and crude ash by combustion in a muffle furnace at $550^{\circ} \mathrm{C}$ for $16 \mathrm{~h}$. Total lipid concentration was determined by the extract with chloroformmethanol method (Bligh and Dyer, 1959). Differences among groups in growth performance and proximate fillet composition were tested with Kruskal-Wallis one-way analysis of variance by ranks (SPSS 10.0 for Windows) followed by the Duncan nonparametric multiple comparison procedure (Zar, 1984).

\section{Results}

Monthly temperature, salinity, dissolved oxygen, and $\mathrm{pH}$ are shown Fig. 1. Water temperature at the surface ranged $16.5-19.0^{\circ} \mathrm{C}$ in December-February, $17.0-20.0^{\circ} \mathrm{C}$ in March-May, $24.5-29.0^{\circ} \mathrm{C}$ in June-August, and $24.0-28.0^{\circ} \mathrm{C}$ in September-November. For the same months, salinity was 35.5-36.1, 36.4-37.4, 37.3-37.8, and 36.2-37.1, dissolved oxygen 8.4-8.7, 7.7-8.1, 6.7-7.2, and 6.7-7.9, and $\mathrm{pH}$ 8.4-8.7, 8.4-8.5, 8.68.7, and 8.0-8.3.

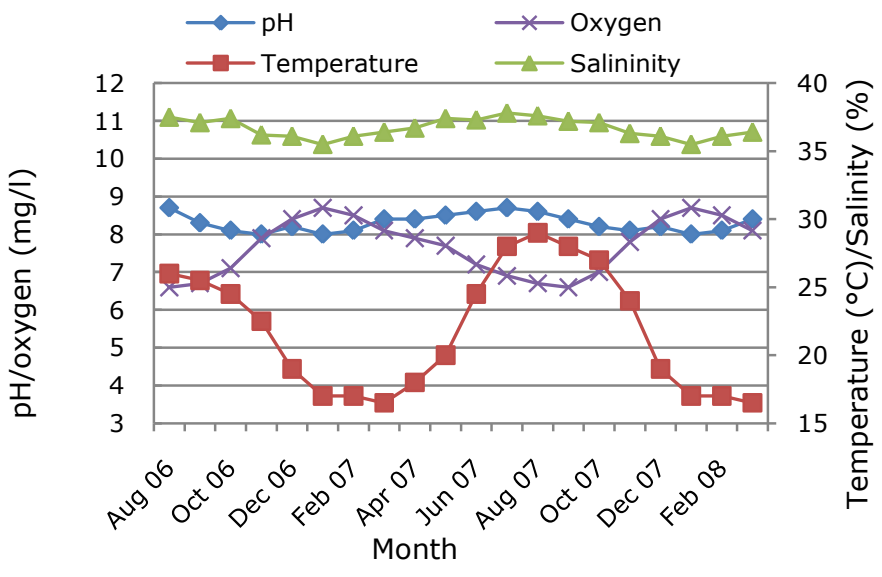

Fig. 1. Monthly salinity, $\mathrm{pH}$, dissolved oxygen, and temperature in offshore cages used to cultivate the Mediterranean amberjack (Seriola dumerili).

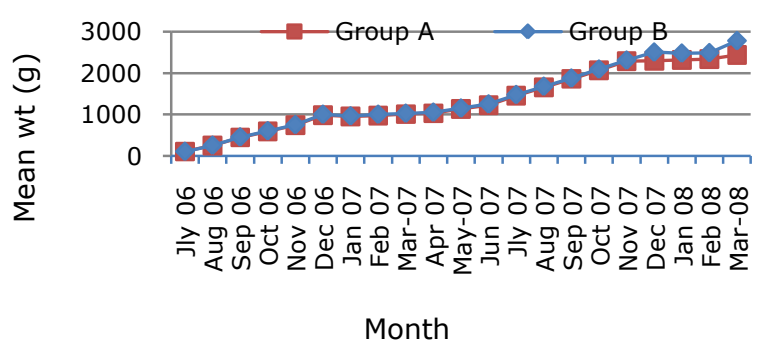

Fig. 2. Monthly average live weight of Seriola dumerili fed pellets only (Group A) or pellets and sardines (Group B).
The wild Mediterranean amberjack juveniles adapted well to captivity conditions and accepted the food provided from their arrival in the offshore culture system onwards. They had a high growth rate throughout the 20 months of rearing. Fish in Group B $(2785.00 \pm 64.91 \mathrm{~g})$ reached a higher weight $(p<0.05)$ than those in Group A (2441 $\pm 38.13 \mathrm{~g})$ by the end of the study (Fig. 2).

At the end of the trial, mortality was $24.8 \%$ and $23.2 \%$ in Groups $A$ and $B$, respectively, due to infection $(20 \%)$ by Zeuxapta seriolae (Monogenea: Heteraxinidae) in December 2006 and handling for monthly measurements $(\sim 5 \%)$ in June 2007 (Table 1).

Survival and feeding parameters did not differ significantly between groups. There were no significant differences in daily live weight gain or SGR except at the end of the experiment (March 2008). The feeding rates were constant, except when they dropped in September 2006. SGR was lowest in December 2006 due to the low water temperature and $Z$. seriolae infection (Fig. 3). FCR did not significantly differ and decreased with the increasing water temperature, as expected (Fig. 4). 
Table 1. Average weight, survival, and feeding parameters of Mediterranean amberjack fed a commercial feed for 20 months (Group A) or a commercial feed for 16 months and frozen sardines for the remaining four months (Group $B$ ).

\begin{tabular}{|c|c|c|c|c|c|c|c|c|c|c|c|c|}
\hline \multirow[t]{2}{*}{ Month } & \multicolumn{2}{|c|}{ Mean wt $\pm S D$} & \multicolumn{2}{|c|}{ Wt range $(g)$} & \multicolumn{2}{|c|}{ Fish (n) } & \multicolumn{2}{|c|}{$\begin{array}{l}\text { Survival } \\
\text { (\%) }\end{array}$} & \multicolumn{2}{|c|}{$\begin{array}{c}\text { Feed } \\
\text { conversion } \\
\text { ratio }\end{array}$} & \multicolumn{2}{|c|}{$\begin{array}{c}\text { Total food } \\
\text { (\%/body wt) }\end{array}$} \\
\hline & $A$ & $B$ & $A$ & $B$ & $A$ & $B$ & $A$ & $B$ & $A$ & $B$ & $A$ & $B$ \\
\hline Aug 06 & $246.72 \pm 21.62$ & $250.11 \pm 21.98$ & $195-285$ & $200-300$ & 250 & 250 & 100 & 100 & 2.46 & 2.23 & 8.20 & 7.43 \\
\hline Sep 06 & $442.61 \pm 26.00$ & $450.27 \pm 24.79$ & $400-490$ & $400-500$ & 250 & 250 & 100 & 100 & 1.16 & 1.10 & 3.86 & 3.66 \\
\hline Oct 06 & $592.16 \pm 25.66$ & $600.00 \pm 27.66$ & $545-648$ & $550-650$ & 250 & 250 & 100 & 100 & 1.85 & 1.81 & 6.16 & 6.03 \\
\hline Nov 06 & $742.22 \pm 27.61$ & $750.00 \pm 28.78$ & $695-800$ & $700-800$ & 250 & 250 & 100 & 100 & 2.35 & 2.28 & 7.83 & 7.60 \\
\hline Dec 06 & $984.72 \pm 34.01$ & $1000.50 \pm 47.16$ & $840-1146$ & $850-1150$ & 200 & 200 & $80^{1}$ & $80^{1}$ & 1.94 & 1.90 & 6.46 & 6.30 \\
\hline Jan 07 & $948.88 \pm 33.27$ & $960.00 \pm 35.86$ & $810-1070$ & $860-1060$ & 200 & 200 & 100 & 100 & 2.03 & 1.99 & 6.76 & 6.63 \\
\hline Feb 07 & $974.72 \pm 34.89$ & $1000.05 \pm 64.94$ & $820-1150$ & $850-1190$ & 200 & 200 & 100 & 100 & 2.21 & 2.15 & 7.36 & 7.10 \\
\hline Mar 07 & $1008.00 \pm 39.75$ & $1025.00 \pm 35.35$ & $900-1095$ & $925-1100$ & 200 & 200 & 100 & 100 & 2.08 & 2.02 & 6.93 & 6.73 \\
\hline Apr 07 & $1027.22 \pm 52.57$ & $1050.00 \pm 40.00$ & $925-1100$ & $950-1100$ & 200 & 200 & 100 & 100 & 1.96 & 1.93 & 6.53 & 6.43 \\
\hline May 07 & $1130.55 \pm 54.10$ & $1150.00 \pm 53.74$ & $1040-1250$ & $1050-1250$ & 200 & 200 & 100 & 100 & 1.97 & 1.95 & 6.56 & 6.50 \\
\hline Jun 07 & $1223.88 \pm 56.58$ & $1250.00 \pm 55.27$ & $1127-1305$ & $1150-1300$ & 188 & 192 & $93^{2}$ & $95^{2}$ & 1.91 & 1.90 & 6.36 & 6.33 \\
\hline Jul 07 & $1453.38 \pm 61.42$ & $1478.16 \pm 57.84$ & $1350-1582$ & $1378-1578$ & 188 & 192 & 100 & 100 & 1.89 & 1.85 & 6.30 & 6.16 \\
\hline Aug 07 & $1657.27 \pm 57.40$ & $1676.00 \pm 54.76$ & $1568-1774$ & $1579-1779$ & 188 & 192 & 100 & 100 & 1.87 & 1.86 & 6.23 & 6.20 \\
\hline Sep 07 & $1860.55 \pm 62.48$ & $1877.00 \pm 56.20$ & 1795-1965 & $1800-1954$ & 188 & 192 & 100 & 100 & 1.91 & 1.90 & 6.36 & 6.33 \\
\hline Oct 07 & $2067.77 \pm 54.92$ & $2095.00 \pm 53.85$ & $1169-2198$ & $1195-2195$ & 188 & 192 & 100 & 100 & 1.92 & 1.89 & 6.40 & 6.30 \\
\hline Nov 07 & $2287.66 \pm 63.47$ & $2313.05 \pm 56.23$ & $2205-2421$ & $2200-2426$ & 188 & 192 & 100 & 100 & 1.95 & 1.90 & 6.50 & 6.33 \\
\hline Dec 07 & $2297.28 \pm 35.02^{\mathrm{a}}$ & $2508.38 \pm 41.31^{b}$ & $2235-2520$ & $2450-2567$ & 188 & 192 & 100 & 100 & 2.04 & 1.95 & 6.80 & 6.50 \\
\hline Jan 08 & $2318.55 \pm 29.31$ & $2483.00 \pm 25.91$ & $2285-2525$ & $2395-2530$ & 188 & 192 & 100 & 100 & 2.16 & 1.99 & 7.20 & 6.63 \\
\hline Feb 08 & $2339.69 \pm 25.40$ & $2594.22 \pm 21.80$ & $2300-2600$ & $2462-2610$ & 188 & 192 & 100 & 100 & 2.25 & 2.06 & 7.50 & 6.86 \\
\hline Mar 08 & $2441.14 \pm 38.13^{a}$ & $2785.00 \pm 64.91^{b}$ & $2380-2693$ & $2540-2820$ & 188 & 192 & 100 & 100 & 1.91 & 2.03 & 6.36 & 6.86 \\
\hline
\end{tabular}

Mean values in the same row with different superscripts significantly differ at $p<0.05$.

${ }^{1}$ mortality due to Zeuxapta seriolae infection

2 mortality due to handling during monthly fish measurement

a

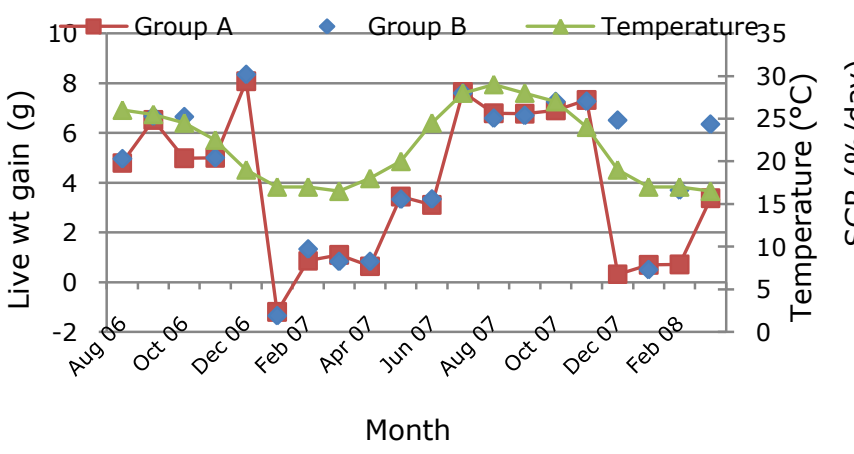

b

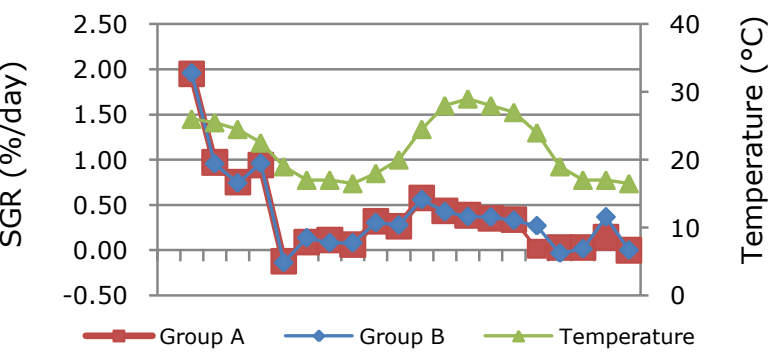

Month

Fig. 3. (a) Daily live weight gain and (b) specific growth rate of Mediterranean amberjack (Seriola dumerili) fed commercial pellets for 20 months (Group A) or commercial pellets for 16 months and frozen sardines for 4 months (Group B).

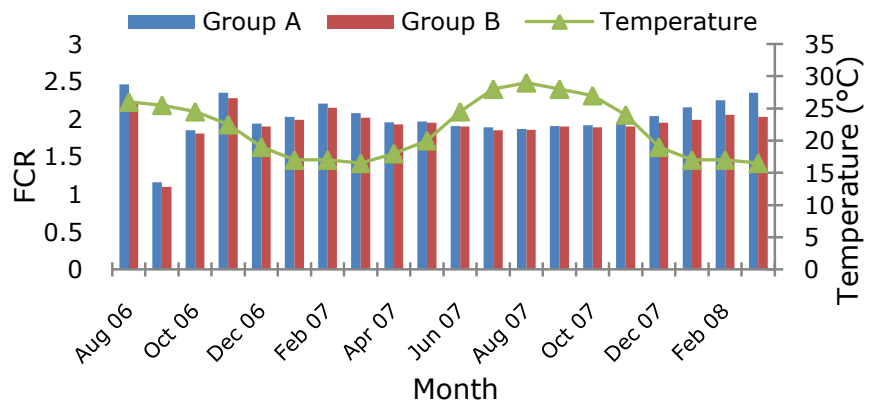

Fig 4. Feed conversion ratios of Mediterranean amberjack fed commercial pellets (Group A) or pellets and sardines (Group B).
The FCR was low in comparison to other studies on amberjacks in the Mediterranean (Table 2). At the end of the feeding trial, fillets of the cultured amberjacks had significantly higher protein and lipid contents than those of wild amberjacks captured by local fishermen in the same area (Table 3 ). On the contrary, moisture and ash contents of the wild amberjacks were higher than those of their farmed counterparts $(p<0.05)$. 
Table 2. Comparison of results with other amberjack cage experiments in the Mediterranean.

\begin{tabular}{|c|c|c|c|c|c|c|c|}
\hline Site & $\begin{array}{l}\text { Cage } \\
\text { system }\end{array}$ & $\begin{array}{l}\text { Initial } \\
\text { wt }(g)\end{array}$ & $\begin{array}{l}\text { Final } \\
w t(g)\end{array}$ & $\begin{array}{c}\text { Cultivation } \\
\text { period } \\
\text { (days) }\end{array}$ & Diet & $F C R$ & Reference \\
\hline Castellammare, Sicily & Floating & 130 & 670 & 85 & Fish scraps & - & Giovanardi et al. 1984 \\
\hline Aeolian Islands, Sicily & Floating & 73 & 858 & 120 & Fish scraps & 4.40 & Porrello et al. 1993 \\
\hline Castellammare, Sicily & Submerged & 48 & 576 & 120 & Pellets & 3.51 & Mazzola et al. 2000 \\
\hline Castellammare, Sicily & Submerged & 48 & 1129 & 120 & Fish scraps & 1.22 & Mazzola et al. 2000 \\
\hline İskenderun Hatay, Turkey & Off-shore & 102 & 2441 & 600 & Pellets & 2.01 & This paper \\
\hline İskenderun Hatay, Turkey & Off-shore & 102 & 2785 & 600 & $\begin{array}{l}\text { Pellets \& frozen } \\
\text { sardines }\end{array}$ & 1.93 & This paper \\
\hline
\end{tabular}

Table 3. Proximate compositions (\%) of farmed and wild amberjack, other fish species, and feeds.

\begin{tabular}{lrrrrr}
\hline & Moisture & Crude protein & Total lipid & Crude ash & Reference \\
\hline Farmed S. dumerili & $73.53 \pm 0.20$ & $21.86 \pm 0.41$ & $2.89 \pm 0.46$ & $1.10 \pm 0.06$ This study \\
Wild captured S. dumerili & $76.51 \pm 0.11$ & $19.61 \pm 0.47$ & $2.03 \pm 0.05$ & $1.33 \pm 0.07$ This study \\
Sparus aurata & $78.20 \pm 1.79$ & $18.08 \pm 0.71$ & $9.80 \pm 1.36$ & $1.37 \pm 0.08$ Grigorakiş et al. 2003 \\
Dicentrarchus labrax & 70.30 & 21.80 & 7.69 & 1.32 Kyrana \& Lougovois 2002 \\
Commercial diet & 9.25 & 45.00 & 22.50 & $9.00-$ \\
Frozen sardine & 75.83 & 20.05 & 0.99 & 3.04 Skaramuca et al. 2001 \\
\hline
\end{tabular}

\section{Discussion}

The mortality rates were $24.8 \%$ in Group A and $23.2 \%$ in Group B. The high mortality resulted primarily from a Zeuxapta seriolae infection during December 2006, which accounted for $20 \%$ mortality. During the infection, the cages were subjected to formalin baths - a $300 \mathrm{ppm}$ solution for $1 \mathrm{~h}$ during every week of infection. This treatment is typically used in aquaculture to exterminate monogeneans. The same procedure was followed before winter in 2007. In addition, the commercial diet was fortified by adding vitamin $C$. No further mortality occurred due to $Z$. seriolae infection after December 2006, indicating that the formalin bath treatments and vitamin C supplementation were effective together. The second incidence of mortality occurred during the monthly fish measurements in June 2007.

The wild captured Mediterranean amberjack juveniles adapted well to the cage conditions, accepting the provided food from stocking in the offshore culture system onwards. The growth rate was high throughout the 20 months of rearing except during winter. During adaptation to the commercial diet (July-September 2006), the fish in both groups accepted the food readily and attained higher specific growth rates than in other months. After adaptation, from winter 2007-8, group B reached a significantly larger size than group $A$, possibly because the amberjacks were observed to feed more readily on the frozen fish than on the commercial pellets.

Wide monthly changes in physico-chemical variables have a significant effect on amberjack growth in floating cages and tanks (Porrello et al., 1993). In our study, changes in growth performance and feed conversion ratios were closely related to water temperature. The growth performance can be divided into two distinct periods: AprilNovember (high) and December-March (low). Different results were obtained in tanks by Garcia et al. (1993) and Skaramuca et al. (2001). The growth and maximum size of Group B were comparable to those obtained in floating cages (Giovanardi et al. 1984; Porrello et al., 1993) and tanks (Cavaliere et al., 1989; Greco et al., 1991). As expected, feed conversion ratios in both groups were higher in the winter than in the warmer months due to bad weather conditions and lower water temperatures. In general, FCR values were better than in earlier attempts conducted in the Mediterranean, except for those of Mazzola et al. (2000). Earlier reports support our findings that amberjack growth performance and daily rate of feeding decrease in autumn and winter (Mazzola et al., 2000; Skaramuca et al., 2001). During the high growth period, feed conversion rates were lower as long as the temperature was above $19^{\circ} \mathrm{C}$. In the low growth period, when temperatures were relatively low $\left(<19^{\circ} \mathrm{C}\right)$, the FCR rose. The difference between these 
two periods should be taken into account in amberjack aquaculture in the Mediterranean as these environmental conditions represent the real situation under which amberjack aquaculture will have to function.

The amberjacks in both groups had similar protein, lipid, ash, and moisture contents at the end of the experiment. Likewise, tank-reared Mediterranean amberjack fed pellets or frozen sardines had similar lipid, ash, moisture, and protein contents (Skaramuca et al. 2001). However, our amberjacks had a higher lipid content than the tank-reared amberjacks and significantly higher protein and lipid contents than wild amberjacks, indicating that Mediterranean amberjacks fed a commercial diet attain higher protein and lipid contents than wild and tank-reared specimens. Farmed Mediterranean amberjack are, thus, high-quality fish with a high percent of protein comparable to that of other farmed species and wild counterparts.

In conclusion, Mediterranean amberjack can be successfully reared in off-shore cage systems and has great aquaculture potential in the northeastern Mediterranean. In the winter, the juveniles consumed the frozen sardines more readily than the commercial feed, thus it is advised to use frozen sardines and/or semi-moist pelleted diets during the winter grow-out period for better feed intake and growth performance. Further research is certainly needed for sustainable culture of Mediterranean amberjack especially in the following areas: feeding strategy, reproductive control, sustainable larval rearing, and nutritional requirements.

\section{Acknowledgements}

This work was funded by the Scientific and Technological Research Council of Turkey, Project No. 105 O 510.

\section{References}

Andaloro F., Potoschi A. and S. Porrello, 1992. Contribution to knowledge of growth of greater amberjack, Seriola dumerili (Cuv. 1817) in the Sicilian Channel (Mediterranean Sea). Rap. Int. Mer Med, 33:282.

AOAC, 1990. Official Methods of Analysis, 15th ed. Assoc. of Official Analytical Chemists, Arlington, VA. $1298 \mathrm{pp}$.

Bligh E.G., and W.J. Dyer, 1959. A rapid method of total lipid extraction and purification. Can. J. Biochem. Physiol., 37:911-917.

Cavaliere A., Crisafi E., Faranda F., Greco S., Lo Paro G., Manganaro A. and A. Mazzola, 1989. Collection of fingerling and rearing of Seriola dumerili in tanks. pp. 119123. In: N. De Pauw, E. Jaspers, H. Ackefors, N. Wilkins (eds.). Aquaculture - $A$ Biotechnology in Progress. N. Eur. Aquacult. Soc., Bredene, Belgium.

Fischer W., 1978. FAO Species Identification Sheets for Fishery Purposes, Western Central Atlantic (Fishing Area 31). Marine Resources Services, Fishery Resources and Environment Division, Fish. Dept., FAO, Rome.

Garcia B., Moreno J. and M.J. Rosique, 1993. Rate of feeding, growth and gross efficiency in juveniles of yellowtail, Seriola dumerili. pp. 255-260. In: Production, Environment and Quality. Eur. Aquacult. Soc. Spec. Publ. No. 18.

Giovanardi O., Mattioli G., Piccinetti C. and G. Smabucci, 1984. Prime esperienze sull'allevamento della Ricciola (Seriola dumerili, Risso 1810) in Italia. Riv. It. Piscic Ittiop. A-XIX, 4:123-130.

Greco S., Arena G., Caridi D. and V. Micale, 1991. An improved method of capture and transport for juveniles of Seriola dumerili. In: N. De Pauw, J. Joyce (eds.). Aquaculture and Environment. Dublin Aquacult., 14:130-131.

Grigorakiş K., Taylor K.D.A. and M.N. Alexis, 2003. Organoleptic and volatile aroma compounds comparison of wild and cultured gilthead sea bream (Sparus aurata): sensory differences and possible chemical basis. Aquaculture, 225:105-119.

Jover M., Garcia-Gomez A., Tomas A., De la Gandara F. and L. Perez, 1999. Growth of the Mediterranean yellowtail (Seriola dumerilii) fed extruded diets containing different levels of protein and lipid. Aquaculture, 179:25-33. 
Kyrana V.R. and V.P. Lougovois, 2002. Sensory, chemical and microbiological assessment of farm-raised European sea bass (Dicentrarchus labrax) stored in melting ice. Int. J. Food Sci. Technol., 37:319-328.

Laroche W.A., Smith-Vaniz W.F. and S.L. Richardson, 1984. Carangidae: development. pp. 510-522. In: H.G. Moser (ed.). Ontogeny and Systematics of Fishes. Spec. Publ. No. 1. Am. Soc. Ichthyol. Herpetol., Allen Press, Lawrence, KA.

Lazzari A., Fusari A., Boglione A., Marino G. and M. Di Francesco, 2000. Recent advances in reproductional and rearing aspects of Seriola dumerilii. pp. 241-247. In: B. Basurco (ed.). Cahiers Options Mediterraneennes, Mediterranean Marine Aquaculture Finfish Species Diversification, vol. 47. CIHEAM, Zaragoza, Spain.

Marino G., Mandich A., Massari A., Andaloro F. and S. Porrello, 1995. Aspects of reproductive biology of the Mediterranean amberjack (Seriola dumerilii Risso, 1810): gonadal development. pp. 115-124. In: B. Basurco (ed.). Cahiers Options Mediterraneennes, Marine Aquaculture Finfish Species Diversification, vol. 16. CIHEAM, Zaragoza, Spain.

Mazzola A., Favaloro E. and G. Sara, 2000. Cultivation of the Mediterranean amberjack, Seriola dumerili (Risso, 1810), in submerged cages in the western Mediterranean Sea. Aquaculture, 181:257-268.

Nakada M., 2000. Yellowtail and related species culture. pp. 1007-1036. In: R.R. Stickney (ed.). Encyclopedia of Aquaculture. Wiley, London.

Pastor E., Grau A., Riera F., Pou S., Massuti E. and A.M. Grau, 2000. Experiences in the culture of new species in the Estacion de Acuicultura of the Balearic Government (1980-1998). pp. 371-379. In: B. Basurco (ed.). Cahiers Options Mediterraneennes, Marine Aquaculture Finfish Species Diversification, vol. 16. CIHEAM, Zaragoza, Spain.

Porrello S., Andaloro F., Vivona P. and G. Marino, 1993. Rearing trial of Seriola dumerili in a floating cage. pp. 299-307. In: Production, Environment and Quality. Eur. Aquacult. Soc. Spec. Publ. No. 18.

Skaramuca B., Kozul V., Teskeredzic Z.J., Bolotin J. and V. Onofri, 2001. Growth rate of tank-reared Mediterranean amberjack, Seriola dumerili (Risso 1810) fed on three different diets. J. Appl. Ichthyol., 17(3):130-133.

Tachihara K., Ebisu R. and Y. Tukashima, 1993. Spawning, eggs, larvae and juveniles of the purplish amberjack (Seriola dumerili). Nippon Suisan Gakkaishi, 59(9):1479-1788.

Takakuwa F., Fukada H., Hosokawa H. and T. Masumoto, 2006. Optimum digestible protein and energy levels and ratio for greater amberjack Seriola dumerili (Risso) fingerling. Aquacult. Res., 37:1532-1539.

Thompson B.A., Beasly M. and C.A. Wilson, 1999. Age distribution and growth of greater amberjack Seriola dumerili, from the north-central Gulf of Mexico. Fish. Bull., 97:362-371.

Zar H., 1984. Biostatistical Analyses. Prentice-Hall, NJ. 